\title{
Introduction: A research agenda for space policy in the 2020s
}

\author{
Kai-Uwe Schrogl, Christina Giannopapa and Ntorina \\ Antoni
}

\section{Why space policy matters}

Gone are the days when the use of space was a domain for scientists. Actually, they never existed. From the first moment of the 'Space Age,' which began with the launch of Sputnik in 1957, the use of outer space occupied a crossroads of a multitude of policy areas, and the multifaceted political dimensions of the use of space became apparent. The term 'Space Race' not only signified the competition of the two superpowers during the Cold War for prestigious 'space firsts' (first satellite, first human in space, the first woman in space, first space-walk, the first robotic Moon landing, first humans on the Moon, first space station, first planetary landing, etc.). It also developed into a distinct area of international relations with the initiation of broadly conceived diplomatic efforts aiming to achieve advantages while also leading to international regulation. The inherent dual-use character of space activities led to a dominance of space utilization as a crucial security factor. This has been the clear constant of space policy until today.

During the past six decades, space policy has been unfolding on this undertone. With the growth of more and more specific uses of outer space and the international proliferation of space technologies, leading to more than 70 countries owning their satellites as of today, the complexity of space policy is growing accordingly. Satellites have become critical infrastructures, without which modern society could not exist anymore. Since the 1960s, telecommunications via satellites connects the continents, and satellite direct broadcasting provides hundreds of millions of households with a continuously growing 
number of TV channels. This area is still commercially the most developed. It was followed by the use of satellites for Earth observation and remote sensing. This has an enormous breadth of applications, ranging from the weather forecast to climate observations and from resource management in agriculture or mining to the management of natural and man-made disasters. More recently, positioning and timing has developed an enormous impact on areas ranging from navigation to precision transactions as in the banking sector. These three satellite application areas present an exploding opportunity for use in all public and private, military, and civilian sectors. With their penetration into the conduct of practically all essential governmental tasks, the character of satellites constitutes critical infrastructure. Space policy sets out how this critical infrastructure is employed and what consequences this has on the national and international levels.

While more than 70 countries use space with their own satellites, getting into outer space is still restricted to a much smaller number of countries. This situation is due to the proverbial complexity of rocket science. States with launching capabilities have strong scientific and industrial capacities and thus have managed to control nuclear power or even have nuclear weapons. For most countries - with the caveat on pre-New Space - nuclear weapons were probably the reason to create launching capabilities. The latter highlights the dual-use character and implication of all space activities again. This fact is less evident with human spaceflight, but the tradition of fighter pilots serving as cosmonauts, astronauts, and taikonauts is to speak a certain language. Human spaceflight is also the ultimate 'club,' scaling down from 70 via 15 to 3 . The Soviet Union/Russia, the US, and lately China are the only countries capable of conducting human spaceflight, also offering numerous partner countries the opportunity to see their nationals in space. With humans in orbit, onboard space stations around the Earth, and visits to the Moon, human spaceflight in the course of the next decades will see trips to orbit, new space stations, a space station around the Moon, and the return to the Moon with the establishment of bases. In parallel, space tourism with suborbital flights will become a commercial, privately-run business. Basic space science is traditionally the area of space activities with the most open and cooperative tradition and culture. But while this might be true for astronomy and cosmology, the field of planetary research is less innocent since it is not only a matter of national prestige to land and operate on the Moon, Mars, comets, or asteroids. With the proliferation of technology, it is also leading to a race for outer space resources as Moon projects from the US, Russia, China, India, Japan, Australia, Europe, Luxembourg, and numerous others demonstrate. And it should not be underestimated that pushing the limits of technology developments in space science and planetary 
exploration has the inherent expectation of transfers to space applications or terrestrial uses.

When distinguishing phases of space policy since the launch of Sputnik in 1957, the first phase was certainly the Cold War superpower competition. One could note the importance not simply in a strategic 'hard power' manner, but in an ideological 'soft power' manner: to win the Global South over to their respective block. The block-building involving also the South was, nevertheless, made through institutions like Intelsat and Intersputnik. During this space race, however, the basic foundations of space law were laid with the 1967 Outer Space Treaty, which, amongst other provisions, guarantees the freedom of use of outer space and the non-appropriation of space. It also contains arms control elements as the prohibition to station weapons of mass destruction in orbit and the non-militarization of the Moon and other celestial bodies. Even before the Outer Space Treaty, the Partial Testban Treaty of 1963 prohibited nuclear explosions in the atmosphere and outer space. It can be argued that since then neither superpower was certain to gain complete superiority and control of outer space, the two agreed to keep it open for further competitive use. This conflict level received an additional layer with the extension of the North-South conflict to outer space later on (Paikowsky, 2017). The main challenges were the fear of developing countries as the late-comers having disadvantages against the 'haves' benefitting from a first-come, first-served regarding satellite orbit positions and frequencies as well as being observed from outer space without their consent by the remote sensing satellites of the superpowers.

Following the collapse of the Soviet Union, a second phase can be described as an age of cooperation where new cooperative ventures emerged, such as the International Space Station with the US, Russia, Europe, Japan, and Canada as main partners (Logsdon, 2007). Numerous global coordination mechanisms amongst space agencies and operators were established. With the advent of increased commercial and emerging private space activities since the first decade of the 2000s, a global space economy is developing. In this context, the term NewSpace is reflecting a third phase, meaning entrepreneurship with private capital and less dependence on government programs, was coined. Today, this global space economy ranges around $\$ 360$ billion and is expected to reach, even taking the effects of COVID-19 into account, \$1 trillion in the early 2030s. Roughly one-quarter of this amount today is governmental spending ( $\$ 90$ billion), with the US alone spending two thirds on this ( $\$ 58$ billion). The leverage effects of satellites for applications may even reach $\$ 10$ trillion in the world economy (WEF, 2020). 
These figures demonstrate the prospects of prosperity emerging from space applications and the space economy. It also shows that space has become a critical infrastructure for governments. This growing dependence on space is accompanied by an even more rampant perception of threats, real or imagined. Thus, space policy is repeating today the scenarios of terrestrial arms races. Together with a belligerent rhetoric, exemplified with the establishment of 'space forces' at the end of the 2010s, the securitization of space activities is in full swing. Governments, in particular China, Russia, and the US, are preparing for outer space becoming a battleground. Diplomacy, in parallel, tries to apply lessons learned from the terrestrial scenarios of the past decades and tries to establish transparency and confidence building measures (Schrogl et al., 2020). At the beginning of the 2020s, bright economic perspectives go hand in hand with military doomsday scenarios.

A brief look at the categories of actors and institutions in space activities completes this overview. States have been and still are the prime actors in outer space. Governments are driving research and development through their spending via space agencies and are operating all types of satellites and have been, until not so long ago, the only actors operating rockets to access space. Private actors need authorization by governments to use outer space and have to be supervised and controlled continuously as the Outer Space Treaty of 1967 foresaws. More and more governments have now enacted national space laws for that purpose, providing the ground for a thriving NewSpace economy. Regional governmental cooperation is a way to pool resources, as shown by Europe in the European Space Agency and its predecessor organizations since the 1960s. While this drew the attention of Latin America, Africa, and Asia as a good example and practice, it has not led to any comparable followers as yet. However, regional approaches such as the emerging approaches from Africa, based on indigenous philosophical and social concepts, can shed light on the development of space policy, governance and law besides the predominant Western concepts and priorities (Aganaba, 2021). Bilateral cooperation amongst the currently around 70 space-faring countries today leads to hundreds of such projects, using the overcome cardinal directions, between North-North, East-West, North-South, and South-South. All this happens in a growing variety of formats for the various space activities and satellite applications. Governments cooperate with each other, governments cooperate with the private sector in other countries, and business cooperates with business transnationally.

Amongst the international institutions which deal with space, the United Nations Committee on the Peaceful Uses of Outer Space (UNCOPUOS), a committee of the UN General Assembly (UNGA), established in 1959, has to 
be mentioned. UNCOPUOS deals with peaceful aspects of international cooperation in outer space and the development of space law. Its pendant on the arms control side is the UN Conference on Disarmament (UNCD), discussing the prospect of an arms race in outer space since 1981. Besides these bodies, the intergovernmental International Telecommunications Union (ITU) is dealing, since the beginning of the space age, with the allocation of frequencies relevant to the use of outer space and satellite services as well as with the allocation of geostationary orbital locations. Numerous international coordination mechanisms, mostly on the level of governmental space agencies, deal with specific issues such as the development of standards for space debris mitigation. Non-governmental international organizations are also growing in number and influence. They today also include civil society that gets organized most prominently in the youth organization Space Generation Advisory Council (SGAC) with around 15000 members in 150 countries.

Space policy matters, because it deals with an issue area that is critical for the functioning of modern society and, on the international level, crucial for the maintenance of peace.

\section{The status of space policy research}

Space policy developed during the 1970s and1980s into an academic research field. Much earlier, space law was established as such. It even saw the creation of an international association of space lawyers with the foundation of the International Institute of Space Law (IISL) as early as 1960. International space law was pioneered in the first part of the 20th century (Hobe, 2013) and during the second part of the 20th century, it led to an impressive number of chairs and university institutes (the earliest in Cologne, Leiden, Montreal and Mississippi) typically combined with air law, dedicated journals (Annals of Air and Space Law, Journal of Space Law, German Journal of Air and Space Law) and book series (currently Studies in Space Law at Brill, Studies in Air and Space Law at Heymanns, IISL Proceedings at Eleven, all with close to or more than 20 volumes). Space policy was a kind of annex to space law research until the 1970s and still remains a very close sibling, with an unusual openness of the space lawyers' profession for political scientists and vice versa. There are numerous examples of the close link between international space law and international space policy from the early days of the Cold War (Zhukov, 1966), the time of the North-South conflict (Jasentuliyana, 1986) to the present (Dunk, 2018). Today, a space lawyer has to understand space policy, and the 
space policy expert cannot do without a solid knowledge of space law. In particular, the character of outer space as a global commons, governed by the non-appropriation principle, intertwines policy and legal aspects extremely tightly - all political questions immediately become legal, all legal questions become immediately political.

Compared with space law, space policy research had a relatively late start and slow development. Up until now, it has not been able to rival space law output and organizational structures. It is, however, today a visible and recognized factor in the field of space policy development with a continuously growing impact. Space policy research is primarily organized in academic institutions, think tanks, and professional associations regarding its institutional manifestation. The establishment of the Space Policy Institute (SPI) at the George Washington University (today at the Elliott School of International Affairs) in 1987 has so far been the only dedicated university institute for space policy education and research. At a growing number of universities, in particular in the field of international relations, professors got interested in space policy, published on the topic, gave courses and initiated theses. As of today, such singular academic flashlights are leading to a continuously growing number of publications and extension of a space policy discourse. While the SPI was and still is primarily an academic educational institution, it also holds the function of a think tank, advising policymakers. In Europe, such a hybrid format was taken by the University of Leuven in the early 2000s, close to the seat of the European Union. In the US, space policy also was taken up early by the pure think tanks, leading to such projects or programs in RAND (Pace et al., 1995), the Aerospace Corporation, or the Center for Strategic and International Studies. In other continents, this was mirrored by think tanks in France (Foundation for Strategic Research (FRS)), French Institute of International Relations (IFRI)), Germany (German Council on Foreign Relations (DGAP), Stiftung Wissenschaft und Politik (SWP), Peace Research Institute Frankfurt (PRIF), Institute for Peace Research and Security Policy at the University of Hamburg (IFSH)), United Kingdom (Chatham House), Italy (International Affairs Institute (IAI)), and Japan (at Keio University). The first, and so far, only dedicated space policy think tanks are the European Space Policy Institute (ESPI) and the Secure World Foundation (SWF). ESPI was established by the European Space Agency (ESA) and the Austrian government in 2003 in Vienna. SWF was founded in 2004 in Colorado, US with the aim to promote the peaceful uses of outer space.

Space Policy has also been a topic for technology assessment since the 1980s. A pioneer in this field was the Office for Technology Assessment (OTA) of the USS Congress (OTA, 1984 and OTA, 1990), but soon technology assessment 
offices in other countries dealt with space technologies and applications, thus influencing space policymaking. To be mentioned are the activities of the technology assessment office of the German Parliament (most recently TAB, 2017) and the European Parliament's Science and Technology Options Assessment (STOA) Network (Panel for the Future of Science and Technology). During the second half of the 1990s, UNESCO's World Commission on Ethics of Scientific Knowledge and Technology prepared a report on the ethics of space policy (Pompidou, 2000). Space has also been continuously a topic for foresight due to the long-term and visionary character, particularly of exploration. Japan was a leader in this field, applying the Delphi approach to space (Cuhls, 2001). Also, the Organization for Economic Cooperation and Development (OECD) has, since the 1980s (OECD, 1985), been investigating the economic impact of space activities, advising its Member States regarding regulations and policies. Likewise, the World Economic Forum (WEF) set up a Global Future Council on Space. Multidisciplinary studies on space activities, including space policy aspects, are regularly undertaken by the International Space University (ISU) and the International Academy of Astronautics (IAA).

There are fewer journals and book series dedicated to space policy than to space law. But since the 1980s, there is a continuously growing academic discourse both in numbers and in quality. In the broad field of international relations journals, space topics have been included since the 1960s (for example, Mickelson already 1969 in Foreign Affairs). Only in 1985, the dedicated journal Space Policy was established at Elsevier and has since then, as a quarterly publication, offered hundreds of articles (30 to 40 per year), commentaries and book reviews to the space policy community. It has a 5-Year impact factor of 1.313. Another Elsevier journal, Acta Astronautica covers all fields of physical, engineering, life, and social sciences related to the peaceful scientific exploration of space with an impact factor of 2.830. Astropolitics is an international journal of space politics and policy by Taylor \& Francis with an impact factor of 0.54 . There are currently two distinct space policy book series. The first was established by ESPI in 2009 as Studies in Space Policy at Springer and counts 25 volumes by today. ESPI has, during some years, also presented study results in the SpringerBriefs series. The other series, Studies in Space Power and Politics, has been published by Routledge and counts five volumes so far. Relevant for space policy research is also the National Aeronautics and Space Administration (NASA) history series (SP-4000 series) and ESA history series in the Explorations Collection from Editions Beauchesne with 12 volumes until 2014.

More and more governmental institutions and industry associations today task the global consultancy companies (such as PWC, Booz Allen Hamilton 
or Bryce) to cover space topics. The discourse on space policy received a particular boost in 1989 with the establishment of Space News, a weekly journal in newspaper style and format, covering all aspects of space activities with an emphasis on space policy developments. It quickly became an essential source for academic research and is today present on the internet with SpaceNews. com. Furthermore, space policy analyses can today also be found in new internet portals as SpacePolicyOnline.com and SpaceWatch.Global.

There does not exist a conference series dedicated exclusively to space policy. However, it is regularly dealt with at the International Astronautical Congress (IAC), the lead conference for space, which usually organizes four space policy sessions. Also, at national or regional congresses organized by space associations, there are from time to time sessions on space policy, usually together with space law. Different to the IISL, there does not exist an international association of space policy researchers. Typically, space policy (together with space law) has its home in social sciences sections of academies, like the global IAA, the French Academie de l'Air et de l'Espace, the Chinese Society of Astronautics, or the Russian Academy of Cosmonautics. There have been singular attempts to establish space policy as a section in political science associations, dealing with international relations, but this has not led to sustainable results. Particularly remarkable was the creation of the already mentioned Space Generation Advisory Council (SGAC) at the turn of the century and also national networks of researchers such as SichTRaum (Sicherheit und Technologie im Weltraum or Security and Technology in Outer Space), looking at human space exploration from the perspective of peace and security. New initiatives in the internet era to bring space policy experts together evolve in particular around the field of exploration, such as the Open Lunar Foundation or the Moon Village Association.

A brief literature review has to start with the solitary publications by John Logsdon on the decision-making in US national space policy (Logsdon, 1970). This seminal work established space policy research as an area of academic research. Two publications in the mid-1980s (McDougall, 1985 and Martinez, 1985) can be singled out since they opened space policy research to new dimensions. They provided the first comprehensive pictures of space policy as an element of international relations. The reception was strong in other space-faring countries at that time, and national research agendas for space policy were set up, such as in Germany (Kaiser \& Welck, 1987). Of particular interest to researchers and scholars was the field of space and arms control. During the 1980s and early 1990s, basic studies were published on this issue (Jasani, 1982; Gasparini, 1991; Doyle, 1994). Space and telecommunications was another field of research (Savage, 1989), which evolved in particular 
around the issue of the equitable use of the Geostationary Satellite Orbit (Levy, 1975; Soroos, 1982; Jakhu et al., 1987) - which has since been the exemplary topic for seminal papers and theses for generations of space policy and space law students.

Continuing the literature review in the 1990s, we see the emergence of think tanks with policy analyses on international relations after the Cold War, touching governance issues on the regional and global level, like whether or not to establish a World Space Organisation (Courteix, 1992). New international relation theories arose (MacDonald, 2007) and were applied to space policy, like the regime analysis (Schrogl, 1993; Wolf, 1991), and more recently (Stuart, 2009; Mutschler, 2013). Also, the ethical aspects in using outer space, technology assessment and space for sustainable development in view of the North-South divide were taken up by scholars and experts from developing countries (Rao, 1996). Proliferation also led to counterapproaches, and space technologies became a field of export control (Aldrin, 1998). The reflection on space policy was particularly pushed by the global United Nations Conferences on the Exploration and Peaceful Uses of Outer Space, in 1968, 1992, and 1999 named UNISPACE I to III (Liebig \& Schrogl, 2000). They shed light on the policy implications of commercialization, privatization, and the emergence of an international space economy.

The last phase of this literature review covers the past 15 years when the breakthrough to establish space policy as an area of political science was achieved. In particular international relations and a more systematic application of international relations theories perspective on space policy was undertaken (Dolman, 2002). This happened for international space policy as a whole (Sheehan, 2008) and for space policy as an issue area of European integration (first, Hoerber \& Stephenson, 2016 and lately, Hoerber \& Forganni, 2021). Based on the focus on space and arms control since the 1980s, the last decade pictured space security as a more comprehensive analytical approach (Moltz, 2008; Schrogl et al., 2020) with a special theme on spacepower, developing into a theory of its own (Bowen, 2020 and the review article by Hays, 2020). In general, the benefits of space for society were seen during the past decade as being more positive than during the early times of rather critical technology assessment approaches (Dick \& Launius, 2007). The subjects, most numerous in articles and papers at conferences, were on the policy aspects of security, exploration, sustainability in space, and the commercialization and privatization of space activities (NewSpace) in a globalizing space economy (Pekkanen, 2019). Consequently, a growing number of country studies has been published since then, reflecting the rapid increase of space-faring countries (Harvey, Smid and Pirard, 2000; Harding, 2013). Most recently, normative approaches of political philosophy, 
as the concept of cosmopolitism, have been applied to space (Schmidt \& Bohacek, 2019). Space policy remains a continuous intellectual challenge in the 2020s.

\section{Space policy key topics for the 2020s}

The topics selected in this Research Agenda for Space Policy draw on the above reflections on why space matters and the interest space policy research has developed during the past half-century. The chapters contain the main questions, which have been continuously in the center of space policy analysis and which are complemented with the most topical contemporary questions possessing the capacity to maintain their importance during the 2020s. In order to provide the reader with the opportunity to compare the topics contained in the thematic chapters in this book, the contributions basically follow six steps. The first step assesses the relevance and importance of the topic. The second step provides a definition and identifies key problems and conflicts related to the specific topic. The third step presents actors and types of institutions involved, including their positions. The fourth step identifies policy and regulatory approaches with possible solutions, asking what is already on the table and what should also be added to the menu to manage the respective topic. The fifth step explores policy and diplomatic mechanisms to reach solutions, proposing new and innovative approaches. Finally, the sixth step contributes to space policy research by analyzing the particular topic and its impact on political science, international relations, space policy, and space law. The chapters slightly vary in the application of this structure, while overall comparability is assured.

Olavo de O. Bittencourt Neto, Professor of space law and policy, highlights in his chapter, "Outer Space as a Global Commons and the Role of Space Law," that space as a global commons has a strategic relevance for space policy. This status is attributed to those areas and resources that fall outside national jurisdiction. The chapter sheds light on the topic by adopting a comparative regulatory approach that draws on the status of the high seas and deep-sea bed, Antarctica, and geostationary orbit. Potential future policy and diplomatic mechanisms concern the legal concept of the common heritage of humankind. Larry Martinez, Professor Emeritus of political science, in his chapter, "International Cooperation and Competition in Outer Space," explores the aspects of the developing 21st Century space policy regime to suggest an analytic framework for understanding space actors' motivations to cooperate or 
compete in both their exploration and use of outer space, and in their participation in outer space governance. The latter is characterized as both a structure and a process. A fundamental problem identified for outer space governance resides with determining the entities who participate in its governance. Policy and diplomatic processes focus on state-level 'subsystem' legislative and regulatory actions responding to the shift of 'soft law', such as 'rules of road' approaches at the international systemic level. Kenneth Hodgkins, President at International Space Enterprise Consultants, and Adam Routh, a PhD candidate at King's College London, discuss in their chapter, "Emergence of and Perspectives for a New Paradigm in Space Diplomacy," how space diplomacy has seen several evolutionary periods. They highlight that though policy and law have changed to accommodate new space activities and challenges, these changes have been influenced more by current diplomatic limitations than space development. The chapter emphasizes the dominant role of COPUOS in advancing international space cooperation and the challenges posed by its consensus decision-making process. Flexibility and forward-thinking are vital features to future diplomatic mechanisms that meet the emerging space development needs.

Kimitake Nakamura, Minister at the Embassy of Japan in the US, addresses in his chapter, "Space Traffic Management for the Future," the relevance of Space Traffic Management (STM) because of growing concerns over orbit congestion, radio-frequency interference, and commercialization of space activities. Policy and regulatory approaches with possible solutions include founding international legal instruments, national directives, and international policy initiatives. Namely, the chapter draws on elements of the Outer Space Treaty, the US Space Policy Directive 3 (SPD-3), and the International Academy of Astronautics (IAA) STM reports of 2006 and 2018. Didier Alary, a space industry expert, emphasizes in his chapter "Approaches to Space Technology Developments" that space technology can be an enabler, and space budget is a unique key for success. The main challenge mentioned on this behalf is that space technology development is not managed internationally. Policy and diplomatic mechanisms explore new international governance models - for instance, an International Civil Space Organization (ICSO) and an International Space Agency (ISA). Arne Sönnichsen, a doctoral candidate in international relations and political science, examines in his chapter, "Militarization and Securitization of Outer Space," how space is seen through lenses of military security. The perceived recent militarization can be attributed to: 1) the symbolic value of a 'space club'; and 2) the rise of new space technologies available to more actors. In this context, space policy research should contribute to defining: a) what does a space weapon/space attack look 
like; b) how an attack can be accounted for; and c) what an appropriate answer could look like as per different strategic cultures.

Pascal Legai, from the European Space Agency, in his chapter "Regional Policy Approaches to Space Security," addresses the concept of space security in Europe, the US, and Asia. The growing ambitions of countries in space are accompanied by excessive competition, including military competition, which can hinder the ability to enhance security by secrecy linked to orbital data, risks escalating into conflict. Future research is called to combine the different security approaches in a new comprehensive framework with perspectives from international relations theory, dominance theory, law, and public governance. Christian Heideck and Niklas Reinke, from the German Aerospace Center (DLR) Tokyo office, discuss in their chapter, "Critical Infrastructure Protection and Space System Resilience," how vitally important organizational and physical structures and facilities rely to a growing extent on a variety of space services. Regulatory approaches to create critical infrastructure resilience focus on bringing together different government agencies concerned with civil protection, counter-terrorism, and cyber-security and creating entities dedicated to critical infrastructure protection at the intersection of these areas as seen in the case studies of the US, the EU, and Japan. Isabelle Sourbès-Verger, from the French National Centre for Scientific Research (CNRS), in her chapter "Space for Public Policies," addresses how the development of private players and the multiplication of national laws raise questions about the evolution of the relationship between space and public policies. Several challenges have to be considered when analyzing the results of technological and organizational changes on critical issues such as new private constellations or the use of space resources. The further development of space for public policy can draw from other academic fields coping with a rapidly changing environment. Annalisa Donati, Lauryn Lee Hallet, and Jean-Jacques Tortora from the European Space Policy Institute elaborate on the case of the Blue Economy in their chapter, "Space and Economic Developments on Earth." Potential synergies and interdependence between space and oceans are highlighted. Space appears as a privileged tool and a key enabling technology to monitor global status of oceans and seas, assess the quality and quantity of available resources, regulate human interactions, and secure traffic and operations.

Fabio Tronchetti, Professor of space law, highlights in his chapter, "Uses of Outer Space Resources," that space resources are a highly relevant topic both from the perspective of the implementation and development of space law as well as for its impact on international relations. Critical problems relate to the lack of clarification for the legal status of such resources and the method chosen to develop rules applicable to space mining. Ultimately, it is up to governments 
to determine how space law will evolve in the area of space resource utilization. In particular, at least some basic rules should be agreed upon internationally, or whether the matter should be left entirely to the individual actions of single states with no mutually recognized international rules. P.J. Blount, a Research Fellow in air and space law, explores in his chapter, "Settling in Space," the new drive to explore and use outer space that makes space settlement a relevant discourse. Several states engage in planetary research, such as China, India, Israel, Japan, Russia, the United Arab Emirates, the United States, as well as the member states of the European Space Agency. An increasing number of commercial actors have emerged that pursue the technology needed for space settlement for its independent commercial values. Rick Wylie, Reader in applied policy science, along with Estelle Godard and Gianluigi Baldesi, address in their chapter "Space, Society and the Public Value," the concept of public value and the implications of its broader perspective on space beyond economic efficiency and market performance. A public value-informed framework perspective is suggested to help identify a possible policy approach embracing the scope and sweep of space technologies, their outputs, and outcomes in the public sphere. Saskia Vermeylen, a socio-legal scholar, in her chapter, "Space as a Source for Inspiration, Identity and the Arts," uses the idea of the aesthetics of international law to explore the modes of self-expression of space law and the wider policy context and discourses employed by NASA and other space actors. Most of the artworks that have been selected for this conversation between space law and critical art practices are embedded and speak to the broader theoretical lens of critical feminist posthumanism and new materialism.

\section{A definition of space policy}

A Research Agenda for Space Policy takes the definition of space policy itself as an object of analysis rather than as the unquestioned premise of a research agenda. In the absence of a commonly agreed definition of space policy, political science and international relations theories are well suited to explore the underpinnings of a space policy definition.

\section{Policy, Polity, and Politics}

Policy is not a self-evident term. In fact, several other languages summarize everything policy, politics, polity related under one general term. For example, 
the German word "politik" and the French word "politique" mean both politics and policy. On the contrary, the English language is more subtle in accentuating different conceptions of the political decision-making process and thus distinguishes policy from politics and polity (Heidenheimer, 1986). Political scientists sought to clarify the divergences by providing distinct definitions for each term. Accordingly, policy is specified as a proposed course of goal-oriented action within a given environment providing obstacles and opportunities (Heclo, 1972), or - as Dye put it prominently as his book title: "What Governments Do, Why They Do It, and What Differences It Makes" (Dye, 1976). Aggregated, this means that policy comprises: a) the materialistic dimension of measurable statistics and indicators and distinct political decisions to be achieved; b) the ideas, (normative) arguments and goals, what in political debate is commented as good or bad; and c) the outcome of a political process. The inquiry into policy sparked a major area of interest in political science labeled 'policy analysis.' For instance, Fischer and Miller, 2007 identified different sorts of 'policy cycles' and typologies of policies: distributive, regulatory, constituent, and redistributive policies (Lowi, 1972). Polity encompasses the institutions of a (political) system. First, before it consists of the formal institutions such as constitutions, legislative texts, certain political organizations such as ministries or parliaments, and their distinct procedural rules. These are the configuration of formally organized institutions that specify the context within which politics and governance occur (Goodin, 2013); second, it consists of informal institutions that could both be interpreted as the core constitutional principles (such as the rule of law, checks and balances, and civil liberties) and in a broader sense, the political culture that, over time, shapes a polity by influencing actors' preferences, perceptions, and identities (Rhodes, Binder, \& Rockman, 2006), and thus discourses. Politics can best be described by classical definitions. Harold Lasswell, with his seminal work, put the definition of politics right on his book cover when he explained politics by: "Who Gets What, When, and How" (1936). In an extension of Lasswell, David Easton described politics as "the authoritative allocation of values for the society" (Easton, 1953: 128). In general, politics describes the decision-making process (Rhodes, Binder, \& Rockman, 2006), which embodies cooperation, conflict, and negotiating of political actors that act within the framework of a polity about policy issues, with certain overlaps between policy and politics.

\section{Space Policy Definition}

Similarly to policy, there is no commonly agreed definition and uniform understanding of space policy. This situation has led to only a few definitions, of which some highlight a normative orientation provided by space policy 
while others focus on a more analytical dimension. For instance, 'space policy' is used to designate the overall framework and define broad orientations and guidance for space activities (Venet \& Schrogl, 2013). On this line, Klein equals "policy" with "strategy" and states: "...policy provides the guidance that establishes the vision, objectives, procedures, and implementing measures for a given course of action" (Klein, 2006). Other definitions carry a heavier focus on an analytical dimension. Here, space policy is regarded as involving both the process - politics - of policy formation and policy change over time and the courses of action taken to achieve political and technological outcomes (Sadeh, 2002). Coletta and Pilch come close to a classical political science policy definition by explaining the general modus operandi of space policy formulation as involving three steps: "(1) the setting of goals by the national leadership; (2) the establishment of appropriate means by administrative agencies to achieve those goals; and (3) the allocation of resources by the administration and congress" (2009).

Moreover, empirically, there is no coherent definition proposed by States about what 'space policy' looks like. States choose arbitrarily what is part of their distinct space policy. Since outer space operations, in general, are academically based on multiple disciplines and empirically crosses several policies such as industry policy, security policy, science policy, and others, we see it as a necessity to provide a guiding definition of space policy to conceptualize different areas of political processes, institutions, and goals. Drawing on political science definitional aspects of policy, polity, and politics, the following definition forms the foundation on which this Research Agenda for Space Policy rests:

"Space policy" consists of the objectives, means, and actions of governmental actors to their uses of outer space under given circumstances.

Objectives comprise normative ideas and policy goals of space-faring actors, including individuals, states, organizations, and private actors. It can provide a strategic vision and a guideline for all concerned stakeholders in order to streamline their activities. Similarly, means can be interpreted from a materialistic perspective of hard power, including military, economic, institutional, technological resources allocated and soft power capabilities, and is overall subject to normative scrutiny (this relates to 'policy'). Actions comprise the actions taken by space-faring actors in order to achieve their goals, for instance, cooperating, conflicting, and negotiating. The actions are closely linked to the contextual dimension and show how actors use their capabilities (here we have 'politics'). In general, we are convinced that since policy is about the authoritative allocation of values in society, a definition of space policy only applies 
to governmental actors such as states, as other relevant actors such as international organizations or non-governmental actors such as non-governmental organizations (NGOs) and commercial actors do not have formal and factual sovereignty to allocate every kind of values - they only have authority in the areas that is granted by the states. Uses of outer space describes all activities in or involving space, both on Earth, as on other objects, in orbits, or in-between space. Given circumstances describes the structural circumstances in which certain space policies are nestled in. This includes formalized institutions such as governance mechanisms (either of national or international origin, depending on the case) and informal institutions, partly as a result of material, institutional, and discursive power distribution (hence 'polity').

\section{Contributions and Boundaries}

This space policy definition aims to further contribute to political science and international relations research. The aim of providing this generic and neutral definition is to encompass almost any facet of these disciplines involved, particularly at the intersection of "policy," "polity," and "politics." To this end, we choose a generic wording that allows a variety of academic disciplines and practitioners' approaches to be applied to the issues at hand. With this definition, we pursue a distinct academic goal that allows inquiring into different aspects contributing to specific space policies of governmental actors. Space policy is a collaborative work of various stakeholders with varying policy goals, and as countries differ fundamentally, the space policy of different actors can vary dramatically. In our definition, we reflect that governmental actors classically do space policy but that several governmental agencies can pursue different space policies. One dividing line could be the perspective on national security on the one side, typically represented by security-related actors such as the military, and a perspective of peaceful coexistence and collaboration, typically represented by a civilian branch of space agencies such as NASA or ESA.

Additionally, we assume that even private actors pursue their own space policy, but that would require a wider interpretation of the ideas, objectives, and circumstances under which they act. Under the strict interpretation of policy, states have authority over a wider number of resources and means, and therefore, they can allocate public resources and can create or change a policy without the need for consultations in order to establish legitimacy (Easton, 1953). A non-governmental actor needs to consult with organizational members and representatives of external stakeholders to develop their strategy. Strategy is a "policy" without the authoritative element. Strategy is defined in management theory as "the determination of the long-term goals 
and objectives of an enterprise, and the adoption of courses of action and the allocation of resources necessary for carrying these goals" (Chandler, 1962).

In this light, this definitional approach seeks to counter taken for granted normative elements that emerge in the absence of a single common understanding of space policy. Normative approaches typically seek to define specific goals that space policy ought to achieve and actions and means to fulfill them by raising questions such as: What is space policy needing to solve? How is space policy needing to be defined to deal with shortcomings? Who are the actors and users enabled by space policy? Be it considerations regarding the public value of space policy, or how it fits a pragmatic world, and whether it is a soft instrument, a guideline, or directive, all these elements relate to space policy value judgment. While appreciating the value of the more analytic normative approaches, they can only represent partial aspects of the definition, such as an element of "objectives." They cannot serve for a value-neutral definition with a generic application. To conclude, this definition is a mapping statement that provides a pathway across all chapters touching upon the various components of space policy.

\section{Theories and methodologies for analyzing space policy - towards a space policy research agenda for the 2020 s}

A research agenda for space policy must be centered on questions related to objectives, means, actions, governmental and non-governmental actors, and given circumstances. Our contributors focus on these elements, building on extant literature and suggesting new directions to expand the scope of inquiry. From the standpoint of law, international relations, and political science, the chapters employ varied theoretical and methodological approaches. All of this is intended to suggest avenues of further research, interesting interactions between research foci that are typically separated due to disciplinary boundaries.

First and foremost, outer space as a global commons created by technology presents researchers and policy practitioners with classic international relations theoretical conundrums long associated with the "prisoner's dilemma" or "tragedy of the commons" analytical frameworks (Chapter 2, Martinez). From a legal perspective, one may classify outer space as an example of global commons since constituting a resource domain to which all nations have legal access. But to properly understand the legal and political consequences of such 
a classification, further comparative studies like the cases of Antarctica, and deep seabed, are recommended, underlying related definitions and assumptions (Chapter 1, Bittencourt). From an international relations theory perspective, the epistemological and analytical challenges posed by issue realms existing outside of States' dense regulatory reach are also illustrated in commons governance wherein both governmental and non-governmental entities directly participate. Three theoretical space governance approaches continue to characterize broad categories of international systemic issues: realism, liberalism, and constructivism. Applying these approaches to space governance assists researchers in identifying those issue clusters most amendable to each approaches' paradigms and explanatory validity. The next steps for future research might focus on how incentives favoring actor contributions to structural governance are out of sync with incentives promoting process governance. Transaction cost theory offers the researcher significant insights into institutional change and regime dynamics (Chapter 2, Martinez). The nature of space as a global commons also touches on international cooperation and diplomacy as the means of understanding, coordinating, and sustaining the use of space as a global commons. The scope and nature of space diplomacy the dialogue between sovereign States on matters related to outer space - has evolved significantly since the dawning of the space age. There is no appetite in the space sector for decades-long negotiations on new binding legal instruments. Instead, a rich menu of legal and policy concepts that space actors can choose from and adapt to their circumstances and goals is urgently needed. Yet, these policy options must balance civil society's needs with mounting space security challenges, like space debris, that, if left unchecked, could render the global commons another tragedy (Chapter 3, Hodgkins and Routh).

In addition, the militarization of outer space is a standing issue, one that is rising due to technological breakthroughs and unabated symbolic value, which leads to securitization. As most space policy research is dominated by law, natural sciences, and engineering, bringing in social sciences could enhance our perception of militarization, weaponization, and securitization. Since it relies on the social dimension, it could shed light on how distinctly clubs played out in past decades and outline a possible future of the 'space club'. That could alert policymakers to the social and symbolic dimension of spaceflight and inspire to find a common narrative for all space-faring actors that could thwart national solo-action (Chapter 6, Sönnichsen). The major space powers are not inclined to favor an updated, completed, and consensual international status in order to keep their technological and strategic lead. Consequently, this situation is a brake to conceptualize and implement more comprehensive space governance structures and to set up a comprehensive cooperative space framework. However, progress has been made in some focused issue-areas 
such as advancing cyber security, developing responsive space capabilities, strengthening critical infrastructure, improving space safety, and refining space technology export controls. Additional efforts are needed to build an internationally recognized stable and sustainable space environment thanks to more a holistic space traffic management (Chapter 7, Legai). The STM notion is posing a significant challenge to the space law regime. If the introduction of further norms beyond the full implementation of US SPD-3 is necessary, multilateral norm-setting, including coordination mechanism, which is unfamiliar in the current space law regime, would probably be necessary. In this sense, SPD-3 has reached a point very close to the 'ceiling' of the traditional method that the space community has implemented. Above the "ceiling", the international community would probably have to initiate a fundamental debate to deeply assess the nature of the outer space law regime (Chapter 4, Nakamura).

Moreover, societies' increasing dependence on space technologies and approaches to protect critical infrastructures by making space systems resilient presents governance challenges. Growing interconnectedness and interdependencies between and among critical infrastructure sectors are part of the digital transformation of the socio-economic system. Governments or political entities will continue to play a key role in owning, operating, regulating, and investing in critical infrastructures. However, when it comes to improving the resilience of technologies in a globalized space domain, the international dimension needs to be taken into consideration when developing and realizing governance mechanisms. Strong partnerships with the private sector will be equally important. Future governance approaches aimed at improving space system resilience as part of critical infrastructure protection will need to further step up efforts to promote exchanges of information, reciprocal confidence-building measures, and potentially adapt public financial planning concerning investments in critical infrastructures (Chapter 8, Heideck and Reinke). Sharing space technologies is therefore critical. Space open-source could be introduced, gather free expert contributions, and ask for major space agencies' support. There is a convergence in the needs, and we should see an increase in the market of common blocks and equipment. There is room for standardization to boost this market, exactly how the CubeSat standards have boosted the first wave of nanosatellites. Without an international organization that will take care of the technical/registration/control of the space traffic, and an International Civil Space Organization (ICSO), there is little hope to imagine a common technology sharing (Chapter 5, Alary). However, the pursuit of activities in outer space has its own constraints that cannot be ignored. Technological considerations sometimes influence public policies, so much so that certain partnerships may come as a surprise, such as South Korea's cooperation with Russia for the development of its national launcher. 
Most often, however, space cooperation reflects multilateral alliances. In parallel, the space capabilities reflect the importance given to them among the national priorities. The analysis of space as the public policy provides original and instructive case studies. The research work that has been done on "European space policy" clearly shows the difficulty of thinking of the European model as a public policy framework. Similarly, the American way of supporting the development of New Space cannot find an equivalent in China. There, we rather see the emergence of opening to commercial space in relation to the modernization of state-owned enterprises (Chapter 9, Sourbès-Verger).

Furthermore, a public value approach provides scholars with a new perspective on the contribution of space beyond the outputs of policies and technologies to their outcomes - their contribution to the common good, giving a wider basis for appreciating and articulating the relevance of space science and technology. It also gives an insight into a new logic for the imagining of wider value possibilities deriving from space policies and missions in the public sphere and allows insight and analysis at an appropriate level of governance necessary to make a material contribution to the common good. This capability is especially important in the polycentric policy environment of NewSpace in which space policy is framed and implemented in a diversity of settings and scales, creating an imperative for a public value governance approach to accommodate the range of new actors seen as legitimate in contribution to space policy with public engagement in structures of co-production giving the public a voice in the void of space (Chapter 13, Wylie, Godard and Baldesi). A realistic governance model could take the form of non-binding guidelines, rules encouraging necessary changes and measures. It also seems crucial to involve the industry and concerned professionals in order to gather their insights at every stage of the whole process. They could even have some influence in decision-making within limits to be set by states. Doing so would ensure that decisions are informed by all the decisive factors and enlightened by the experience of effectively concerned actors (Chapter 10, Donati, Hallet, and Tortora).

Finally, the topic of the management and use of outer space has significant implications both on the stability of international relations as well as on the progress of space law. In particular, analysis has revealed how challenging it is to elaborate a common approach on a topic, such as the commercial use of space resources, that combines economic, political, and technological elements, and how notable are the effects that these challenges create at international level. Indeed, not only have States expressed opposing views on the governance of space resources, but they have also questioned the form that international discussions have taken and the fora in which they have taken place. Still, the process of elaboration of an international regulatory frame- 
work applicable to space resource utilization activities perfectly highlights the difficulties associated with combining principles drafted several decades ago with the interests and needs of 21st century's space actors of governmental and non-governmental nature (Chapter 11, Tronchetti). Along a similar line, the import of thinking about space settlement is not necessarily connected to the establishment of the settlements. The unraveling of the political and legal questions connected to space settlement brings us closer to understanding the moral and ethical foundations of governance structures (Chapter 14, Vermeylen).The uniqueness of these environments enables us to contemplate politics and law outside of our current realm of existence, which could very well serve to advance our understanding not just of governance in the space context but governance in the terrestrial context as well (Chapter 12, Blount).

International relations, political theory, and (international) law have only recently starting to engage with new materialism and feminist posthumanism. The recognition of the non-human agency of matter and treating planetism with its stars and asteroids not as legal subjects that can be appropriated but as legal objects that can stand up for their legal future may change the level playing field for space travel (Chapter 14, Vermeylen).

\section{Conclusion}

A Research Agenda for Space Policy represents an international collaborative project aiming to effectively address the multifaceted concept of space policy. The distinguished group of contributors, counting academics and practitioners alike from several countries and diverse institutions, provide unique disciplinary perspectives in their chapters. The editing process was based on a continuous dialogue including theory contributions and implications for practice that extended in the reviewing process. The authors also served as peer-reviewers for each other's chapters. This teamwork enabled for cross-references and cross-checks between the various disciplines concerning the space policy components addressed. We thank all contributors for their work on this volume and their enthusiastic engagement in this project. Special thanks to Arne Sönnichsen in editing this introduction. We are much indebted to Daniel Mather for guiding us so perfectly through the editorial process of Edward Elgar Publishing. This work aims to provide a sophisticated, cutting-edge resource and assist fellow members of the global space community, academic audiences, and many others interested in keeping abreast of the current and future directions of space policy. 


\section{References}

Aganaba, T. (2021) New Space through an African Lens, Special Issue of New Space (9) 1.

Aldrin, A. J. (1998). Technology control regimes and the globalization of space industry. Space Policy, 37 (11), 115-22.

Bowen, B. (2020). War in Space. Strategy, Spacepower, Geopolitics. Edinburgh: University Press.

Coletta, D. V. \& Pilch, F. T. (2009). Space and Defense Policy. Eisenhower Center for Space and Defense Studies. London, New York: Routledge (Space Power and Politics).

Courteix, S. (ed.) (1992). Faut-il créer und Organisation mondiale de l'espace?. Paris: La Documentation Francaise.

Chandler, A. D. (1962). Strategy and Structure. MIT Press, Cambridhe, Mass., 1962.

Cuhls, K. (2001). Foresight with Delphi Surveys in Japan. Technology Analysis and Strategic Management, 13 (4), 555-69.

Dick, S. J. \& Launius, R. D. (eds.) (2007). Societal Impact of Spaceflight. Washington, DC: NASA SP-2007-4801.

Dolman, E. C. (2002). Astropolitik. Classical Geopolitics in the Space Age. London, Portland: Frank Cass.

Doyle, S. E. (1994). Civil Space Systems. Implications for International Security. Aldershot: Dartmouth/ UNIDIR.

Dunk, F. von der (ed.) (2018). International Space Law. Cheltenham: Edward Elgar Publishing.

Dye, T. R. (1976). Policy Analysis: What Governments Do, Why They Do It, and What Differences It Makes. Tuscaloosa: University of Alabama Press.

Easton, D. (1953). The Political System: An Inquiry into the State of Political Science. New York: Alfred A. Knopf.

Fischer, F. \& Miller, G. J. (2007). Handbook of Public Policy Analysis - Theory, Politics, and Methods. New York: Routledge.

Gasparini, A. P. (1991). Prevention of an Arms Race in Outer Space: A Guide to the Discussions in the Conference on Disarmament, New York: UNIDIR/91/79.

Goodin, R. E. (2013). The Oxford Handbook of Political Science. Oxford: Oxford University Press.

Harding, R. C. (2013). Space Policy in Developing Countries. The Search for Security and Development on the Final Frontier. London, New York: Routledge (Space Power and Politics).

Harvey, B., Smid, H. \& Pirard T. (2000). Emerging Space Powers. The New Space Programs of Asia, the Middle East, and South America, Chichester: Springer/Praxis Publishing.

Havercroft, J. \& Duvall, R. (2009). Critical Astropolitics. The Geopolitics of Space Control and the Transformation of State Sovereignty. In: Natalie Bormann und Michael J. Sheehan (ed.): Securing Outer Space. London, New York: Routledge, S. 42-58.

Heclo, H. (1972). Review Article: Policy Analysis. British Journal of Political Science, 2(1), 83-108.

Hays, P. L. (2020). Spacepower Theory and Organizational Structures. In: Schrogl, K.-U., Adriaensen, M., Giannopapa, C., Hays, P. L., Robinson, J. and Antoni, N. 
(eds.), Handbook of Space Security. Policies, Applications and Programmes. 2 vol., 2nd edition, New York: Springer, pp. 49-72.

Heidenheimer, A. J. (1986). Politics, Policy and Policy as Concepts in English and Continental Languages: An Attempt to Explain Divergences. The Review of Politics, 48(1), 3-30.

Hobe, S. (ed.) (2013). Pioneers of Space Law. Leiden: Martinus Nijhoff Publishers/ International Institute of Space Law.

Hoerber, T. \& Forganni, A. (eds.) (2021). European Integration and Space Policy. A Growing Security Discourse. London: Routledge.

Hoerber, T. \& Stephenson, P. (eds.) (2016). European Space Policy. European Integration and the Final Frontier. London: Routledge.

Jakhu, R. S., Magdelenat, J. L. \& Rouselle, H. (1987). The ITU Regulatory Framework for Satellite Communications: An Analysis of Space Warc 1985. The Politics of International Telecommunications, 42 (2), 276-88.

Jasani, B. (ed.) (1982). Outer Space. A New Dimension of the Arms Race. London: Routledge.

Jasentuliyana, N. (1986). The UN Space Treaties and the Common Heritage Principle. Space Policy, 4 (4), 296-304.

Kaiser, K. \& Welck, S. von (eds.) (1987). Weltraum und internationale Politik. Munich: Oldenbourg.

Klein, J. J. (2006). Space Warfare: Strategy, Principles and Policy. London, New York: Routledge.

Lasswell, H. D. (1936). Politics. Who Gets What, When, and How. New York: Whittlesey House.

Levy, S. A. (1975). INTELSAT: Technology, Politics and the Transformation of a regime. International Organization, 29 (3), 655-80.

Liebig, V. \& Schrogl, K.-U. (2000). Space Applications and Policies for the New Century. The Impact of the Third United Nations Conference on the Exploration and Peaceful Uses of Outer Space (UNISPACE III) 1999, Frankfurt am Main: Peter Lang.

Logsdon, J. M. (1970). The Decision to Go to the Moon: Project Apollo and the National Interest, Cambridge, MA: MIT Press.

Logsdon, J. M. (2007). Space in the Post-Cold War Environment. In: Steven J. Dick and Roger D. Launius (eds.): Societal Impact of Spaceflight. Washington, DC: National Aeronautics and Space Administration, Office of External Relations, History Division (The NASA History Series, 4801), S. 89-103.

Lowi, T. J. (1972). Four Systems of Policy, Politics, and Choice. Public Administration Review, 32 (4) 298-310.

MacDonald, F. (2007). Anti-Astropolitik - Outer Space and the Orbit of Geography. Progress in Human Geography, 31 (5), S. 592-615.

Martinez, L. (1985). Communication Satellites. Power Politics in Space. Boston and London: Artech House.

McDougall, W. A. (1985)....the Heavens and the Earth. A Political History of the Space Age. New York: Basic Books.

Mickelson, S. (1969). Communication by Satellite, Foreign Affairs, 48 (1), 67-79.

Moltz, J. C. (2008). The Politics of Space Security: Strategic Restraint and the Pursuit of National Interest. Standford, CA: Stanford University Press.

Mutschler, M. M. (2013). Arms Control in Space. Exploring Conditions for Preventive Arms Control. London: Palgrave Macmillan.

OECD (1985). The Space Industry. Trade Related Issues, Paris: OECD. 
OTA (1984). Remote Sensing and the Private Sector. Issues for Discussion. A Technical Memorandum, Washington, DC: OTA-TM-ISC-20.

OTA (1990). Orbiting Debris. A Space Environmental Problem. Background Paper, Washington, DC: OTA-BP-ISC-72.

Pace, S. et al. (1995). The Global Positioning System. Assessing National Policies, Santa Monica: RAND.

Paikowsky, D. (2017). What is New Space? The Changing Ecosystem of Global Space Activity. In: New Space 5 (2), S. 84-88.

Pekkanen, S. M. (2019). Governing the New Space Race. AJIL Unbound 113, S. 92-97.

Pompidou, Alain (ed.) (2000). The Ethics of Space Policy. Paris: UNESCO.

Rao, U. R. (1996). Space Technology for Sustainable Development. New York: McGraw-Hill.

Rhodes, R. A., Binder, S. A., \& Rockman, B. A. (2006). The Oxford Handbook of Political Institutions. New York: Oxford University Press.

Sadeh, E. (2002). Space Policy and Politics - An Evolutionary Perspective. US: Kluwer.

Savage, J. G. (1989). The Politics of International Telecommunications Regulation, Boulder, CO: Westview Press.

Schmidt, N. \& Bohacek, P. (2019). Dawn of Cosmopolitan Order? The New Norm of Responsibility to Defend Earth and the Plnetary Council. In: N. Schmidt (ed.), Planetary Defense: Global Collaboration for Defending Earth from Asteroids and Comets, pp. 315-338. Cham: Springer.

Schrogl. K.-U. (1993). Zivile Satellitennutzung in internationaler Zusammenarbeit, Cologne: Carl Heymanns.

Schrogl, K.-U., Adriaensen, M., Giannopapa, C., Hays, P. L., Robinson, J. \& Antoni, N. (eds.) (2020). Handbook of Space Security. Policies, Applications and Programmes, 2 vol., 2nd edition, New York: Springer.

Sheehan, M. (2008). The International Politics of Space. London: Routledge.

Soroos, M.S. (1982). The Commons in the Sky: The Radio Spectrum and Geosynchronous orbit as issues in global policy. International Organization, 36 (3), 665-77.

Stuart, J. (2009). Unbundling Sovereignty, Territory and the State in Outer Space. Two Approaches. In: Natalie Bormann and Michael J. Sheehan (eds.), Securing Outer Space. London, New York: Routledge, S. 8-23.

TAB (Büro für Technikfolgenabschätzung beim Deutschen Bundestag) (2017). Wettlauf in eine neu Weltraumära, Berlin: Themenkurzprofil 13.

Venet, C., \& Schrogl, K.-U. (2013). European Experiences with Space policies and strategies. In: E. Sadeh, Space Strategy in the 21st Century, pp. 263-278. New York: Routledge.

WEF (2020). Six ways space technologies benefit life on Earth. Cologny/Geneva: WEF.

Wolf, K. D. (1991). Internationale Regime zur Verteilung globaler Ressourcen. Eine vergleichende Analyse der Grundlagen ihrer Entstehung am Beispiel der Regelung des Zugangs zur wirtschaftlichen Nutzung des Meeresbodens, des geostationären Orbits, der Antarktis und zu Wissenschaft und Technologie. Baden-Baden: Nomos.

Zhukov, G. (1966). The Moon, Politics, and Law, International Affairs (Moscow), 32-7. 